\title{
Role of Gum Acacia in Serum Packed Cell Volume Correlated To Anemia among Patients with Renal Disease
}

\author{
Suad Y Alkarib ${ }^{1 *}$, Nahla A Mohamed ${ }^{2}$, Elsir A Groun ${ }^{3}$ and Mohamed B Ghalib ${ }^{1}$ \\ ${ }^{1}$ University of Karary, Sudan \\ ${ }^{2}$ Princess Nora bint Abdulrahman University, KSA \\ ${ }^{3}$ University of Science and Technology, Sudan
}

Submission: December 30, 2016; Published: February 07, 2017

*Corresponding author: Suad Y Alkarib, College of Pharmacy, University of Karary, Omdurman, Sudan, Tel: 2499123047 39;

Email: ombasil1@yahoo.com

\begin{abstract}
Gum Arabic acacia is a complex polysaccharide, aggregates of sugars and hemicelluloses composed of Arabic acid nucleus, it is found in nature as slightly acidic calcium, magnesium, potassium or sodium salt and there is different metal ions present in gum arabic molecules. Chemically, it is an arabinogalactan-protein complex composed by weight of $17-34 \%$ arabinose, $32-50 \%$ galactose, $11-16 \%$ rhamnose, $13-19 \%$ glucuronic acid and 1.8-2.5\% protein. Renal diseases are manifested in alteration in blood cell count, disturbance in all blood components values which found to be very common among those patients. PCV is the percentage of red blood cells in circulating blood. A decreased PCV generally means red blood cell loss from any variety of reasons like cell destruction, blood loss, and failure of bone marrow production. An increased PCV generally means dehydration or an abnormal increase in red blood cell production. The hematocrit is known as packed cell volume (PCV) or erythrocyte volume fraction (EVF), normally $45 \%$ for men and $40 \%$ for women. This is a common scenario with CKD cats. The normal PCV may fool the result on rehydration; remember that both numbers will drop leaving you with an anemia. It is a Randomized control trial study, using volunteers with different Kidneys function with six months past history records. Upgrading dose of 10 , 15, 20, 25 grams of gum dissolved in $250 \mathrm{ml}$ drinking water to be taken daily morning, for duration of 16-18 weeks with interval every four weeks for every dose. Blood samples were taken for PCV analysis first as a control, and after every dose before starting the next one. (Tables $1 \& 2$ ) Gum acacia has a significant role on serum PCV with correlation to iron contents in the blood.
\end{abstract}

Objective of this study: This study aimed to investigate the role of gum arabic in the packed cell volume which highly related to cell iron contents and so serum hemoglobin level. Among patents in different centers for kidney diseases in Khartoum.

Rationale of the study: In favour of a positive effect, work performed over 10 years ago in Khartoum, suggested beneficial effect on blood biochemistry following dietary supplementation with $50 \mathrm{~g}$ /day in patients with CKD. A similar finding has recently been reported from the Central Sudan [1]. It should be emphasized however that these findings are not universally accepted and shortfalls in study design as well as studies with less dramatic effects on renal function have recently been highlighted [2]. To date, although there are numerous health claims which are made for dietary supplementation with Gum Arabic, however these are not widely accepted in clinical practice. It is clear that a structured program of clinical studies as a "proposed clinical trial protocol of Gum Arabic use in chronic kidney disease" The dose selected to be used in the trial will be the least effective dose of Gum Arabic that lowers the serum indoxylsulphate and increases the SCFAs concentrations, supported by good mechanistic basic science is now needed to Exploring the potential health benefits of Gum Arabic, to reestablish a medical application for Gum Arabic.

Keywords: Gum acacia; Serum cells count; PCV and Anaemia

Abbreviations: PCV: Packed Cell Volume; EVF: Erythrocyte Volume Fraction; VPRC: Volume of Packed Red Cells; Ht or HCT: Hematocrit; HbF: Fetal Haemoglobin; SCA: Sickle Cell Anaemia; GA: Gum Arabic; SCD: Sickle-Cell Disease; SD: Standard Deviation 
Table 1: PCV levels showed biological increment readings.

\begin{tabular}{|c|c|c|}
\hline 10 grams dose & $\begin{array}{c}(36.893+/-3.814 \\
\text { before, and } 37.286 \\
+/-3.142 \text { after })\end{array}$ & with p-value 0.768 \\
\hline 15 grams dose & $\begin{array}{c}(36.893+/-3.814 \\
\text { before, and } 37.536 \\
+/-2.341 \text { after })\end{array}$ & with p-value 0.595 \\
\hline 20 grams dose & $\begin{array}{c}(36.893+/-3.814 \\
\text { before ,and } 37.857 \\
+/-3.183 \text { after })\end{array}$ & with p-value 0.474 \\
\hline 25 grams dose & $\begin{array}{c}(36.893+/-3.814 \\
\text { before, and } \\
38.071+/-3.339 \\
\text { after })\end{array}$ & with p-value 0.115 \\
\hline
\end{tabular}

Table 2: Hb readings: iron contents.

\begin{tabular}{|c|c|}
\hline 10 grams dose & $\begin{array}{c}(11.821 \text { baseline and } 11.78 \\
\text { after+/- } 0.893 \text { with P-value } 0.9)\end{array}$ \\
\hline 15 grams dose & $\begin{array}{c}(11.821 \text { baseline and } 11.99 \\
\text { after+/-1.075 with P-value } 0.7)\end{array}$ \\
\hline 20 grams dose & $\begin{array}{c}(11.821 \text { baseline and } 12.0 \\
\text { after+/-0.953 with P-value } 0.5)\end{array}$ \\
\hline 25 grams dose & $\begin{array}{c}(11.821 \text { baseline and } 12.1 \\
\text { after+/- } 1.149 \text { with } P \text {-value } 0.5)\end{array}$ \\
\hline
\end{tabular}

\section{Introduction}

Chronic kidney failure due to sickle-cell nephropathy manifests itself with hypertension, protein loss in the urine, loss of red blood cells in urine and worsened anaemia. If it progresses to end-stage renal failure, it carries a poor prognosis [3]. Gum Arabic is proved to be effective in improving the renal profile in patients with kidney disease [4]. Hematocrit is also sometimes called packed cell volume (PCV), volume of packed red cells (VPRC), or erythrocyte volume fraction (EVF). The term hematocrit comes from the Ancient Greek words

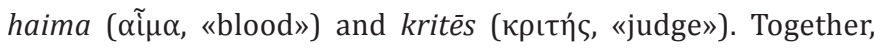
hematocrit means «to separate blood». It was coined by Magnus Blix at Uppsala in 1891 as haematokrit modeled after lactokrit, which was used in dairy farming. The hematocrit (Ht or HCT), also known by several other names, is the volume percentage (vol \%) of red blood cells in blood. It is normally $45 \%$ for men and $40 \%$ for women [5]. It is considered an integral part of a person's complete blood count results, along with hemoglobin concentration, white blood cell count, and platelet count. Because the purpose of red blood cells is to transfer oxygen from the lungs to body tissues, a blood sample's hematocrit-the red blood cell volume percentage-can become a point of reference of its capability of delivering oxygen.

Additionally, the measure of a subject's blood sample's hematocrit levels may expose possible diseases in the subject. Anemia refers to an abnormally low hematocrit, as opposed to polycythemia, which refers to an abnormally high hematocrit. Clinically the packed cell volume (PCV) can be used as a simple screening test for anaemia, as a reference method for calibrating automated blood count systems, and as a rough guide to the accuracy of haemoglobin measurements, hemodilution, hemoconcentration. It can be used in the calculation of red cell indices. However, its use in under- resourced laboratories may be limited by the need for a specialized centrifuge and a reliable supply of capillary tubes. Trapping plasma increase the PCV in macrocytic anemias, spherocytosis, thalassemia, hypochromic anemias and sickle cell anemia. Both are potentially lifethreatening disorders. The packed cell volume or haematocrit (PCV) is a measurement of the ratio of the volume occupied by the RBCs to the volume of whole blood in a sample of capillary or venous blood [6]. There are many diseases that can be detected by testing Hematocrit. Anemia, a condition of low red blood cell count, is the most common blood disorder. There are also diseases of increased red blood cells, Polycythemias, which increase the viscosity of the blood and can cause a wide variety of symptoms [7,8]. Abnormal Hematocrit may also indicate illness.

For example, chronic obstructive pulmonary disease can cause an increase in the production of red blood cells while a low red blood cell count could be an indication of a hemorrhage or ectopic pregnancy [8]. Three-quarters of sickle-cell cases occur in Africa. A recent WHO report estimated that around $2 \%$ of newborns in Nigeria were affected by sickle cell anaemia, giving a total of 150,000 affected children born every year in Nigeria alone. The carrier frequency ranges between $10 \%$ and $40 \%$ across equatorial Africa, decreasing to $1-2 \%$ on the North African coast and $<1 \%$ in South Africa WHO [9]. There have been studies in Africa that show a significant decrease in infant mortality rate, ages 2-16 months, because of the sickle-cell trait. This happened in predominant areas of malarial cases [10]. High levels of fetal haemoglobin ( $\mathrm{HbF}$ ) decrease sickle cell anaemia (SCA) severity and leads to improved survival. According to in vivo and in vitro studies, butyrate increases $\mathrm{HbF}$ production. Its utilization in clinical practice is hampered, however, by its short half-life. Serum butyrate concentrations could be enhanced by colonic bacterial fermentation of Gum Arabic (GA), edible, dried, gummy exudates from Acacia Senegal tree. We hypothesized that regular intake of GA increases serum butyrate levels, thus inducing $\mathrm{HbF}$ production and ameliorating symptoms of sickle cell anemi. Sickle-cell disease (SCD) is a group of blood disorders typically inherited from a person's parents. The most common type is known as sickle-cell anaemia (SCA).

It results in an abnormality in the oxygen-carrying protein haemoglobin found in red blood cells. This leads to a rigid, sicklelike shape under certain circumstances. Problems in sickle cell disease typically begin around 5 to 6 months of age [11]. Polycythemia vera is a clonal disorder arising in a multipotent hematopoietic progenitor cell that causes the accumulation of morphologically normal red cells, white cells, platelets, and their progenitors in the absence of a definable stimulus and to the 
exclusion of nonclonal hematopoiesis. First described in 1892, Polycythemia vera is not a new disease and while uncommon, with an incidence of at least 2 per 100000 , it is not a rare disease. Yet, after 10 decades of careful clinical and laboratory investigation, the etiology of Polycythemia vera remains unknown and there is no consensus as to the optimal therapy for the disorder [12]. The detection and diagnostic classification of iron-restricted erythropoiesis can be a challenging process for the clinician. In the past, the diagnosis of iron deficiency anemia was seemingly straightforward, based on traditional biochemical markers such as serum iron, iron saturation and ferritin from the chemistry laboratory. The anemia of chronic disease was considered a diagnosis of exclusion based on an evaluation excluding absolute iron deficiency and of other possible, known causes of anemia.

\section{Materials and Methodology}

Gum Acacia from Kordofan region in west Sudan was collected and prepared as required for usage in this study. Its natural plantbased materials characterize as biodegradable which represent truly renewable source and they have no adverse impact on humans or environmental health, also are biocompatible and non-toxic because all of these plant materials are carbohydrates composed of repeating sugar (monosaccharides) units. It is always cheaper to use natural sources. The production cost is also much lower compared with that for synthetic material. It is environmental friendly and easily collected in different seasons in large quantities due to the simple production processes and a suitable strategy is required to save money and time [13].

\section{Type of the study}

It is a randomized clinical trial study.

\section{Ethical consideration}

The study protocol was ethically reviewed and approved by the ethical reviewing committee of the research directorate Federal Ministry of Health, Khartoum.

\section{Place of the study}

In Khartoum different Known Kidney disease centers, Salma center, Ibn Seena, Ahmed Gasim and Arif. These are the senior referral hospitals in Sudan. Patients from all over the country are used to be referred to these centers; hence a sample recruited from these centers is considered representative to Sudan population.

\section{Population of the study}

Call for participation was announced in the nominated hospitals. Volunteers with different stages of renal impairment for the past six months were reported. Those fulfilled the inclusion criteria were approached and asked to participate. A written consent was signed by the patients themselves. The study performed using volunteers with different Kidneys function with six months past history records. Dose of 10,15 , 20, 25 grams of gum dissolved in $250 \mathrm{ml}$ drinking water to be taken daily morning, for duration of 16-18 weeks with interval every four weeks for every dose. Blood samples were taken for PCV and iron contents analysis first as a control, and after every dose before starting the next one.

\section{Dosage of gum arabic}

The minimal lethal dose was determined as follows:

i. Different weights of gum arabic in instant soluble form were dissolved into $250 \mathrm{ml}$ of drinking water.

ii. The weights were $10 \mathrm{~g}, 15 \mathrm{~g}, 20 \mathrm{~g}$, and $25 \mathrm{~g}$.

iii. All the volunteers were started with the $10 \mathrm{~g}$ in $250 \mathrm{ml}$ water taken for 4 weeks.

iv. The dose was given orally in early morning on daily basis. It was then upgraded to $15 \mathrm{~g}, 20$ and finally to $25 \mathrm{~g}$ each for 4 weeks interval.

v. 3mls of venous blood was collected in tube before the first dose to determine the baselines PCV level and $\mathrm{Hb}$.

vi. Blood samples were collected at the end of last week for each dose interval.

vii. All the samples were analyzed for serum PCV and Hb in Alburj lab in the center of Khartoum city.

viii. The data was computed in SPSS version 20 and ANOVA was obtained.

\section{Results}

\section{Statistical data analysis}

Were done based on mean +/- standard deviation (SD) using ANOVA statistical one way to investigate the variance significance. In all analysis of data generated from in vivo studies the probability p-value 0.05 was considered as appoint for significance. (Individual 95\% CIs for Mean Based Pooled St-Dev) (Tables 3 \& 4) (Figures 1-4) [4].

Table 3: Significance of serum packed cell volume before and after administration of gum arabic. Standard reference value (range is $40-$ 45). (Figures $1 \& 2$ ) Gum arabic is proved to be effective in improving the renal profile in patients with kidney disease [4].

\begin{tabular}{|c|c|c|c|}
\hline Dose & $\begin{array}{c}\text { Readings } \\
\text { before }\end{array}$ & Readings after & p-value \\
\hline 10 grams & $36.893+/-3.814$ & $37.286+/-3.142$ & 0.768 \\
\hline 15 grams & $36.893+/-3.814$ & $37.536+/-2.341$ & 0.595 \\
\hline 20 grams & $36.893+/-3.814$ & $37.857+/-3.183$ & 0.474 \\
\hline 25 grams & $36.893+/-3.814$ & $38.071+/-3.339$ & 0.115 \\
\hline
\end{tabular}




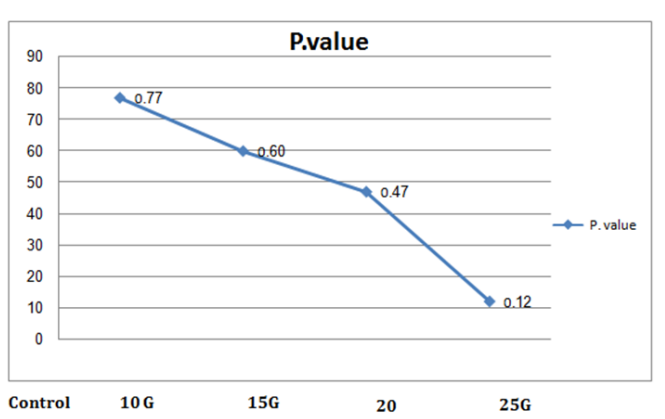

Figure 1: Declined P-values after increased gum dose from 10 grams to 25 grams.

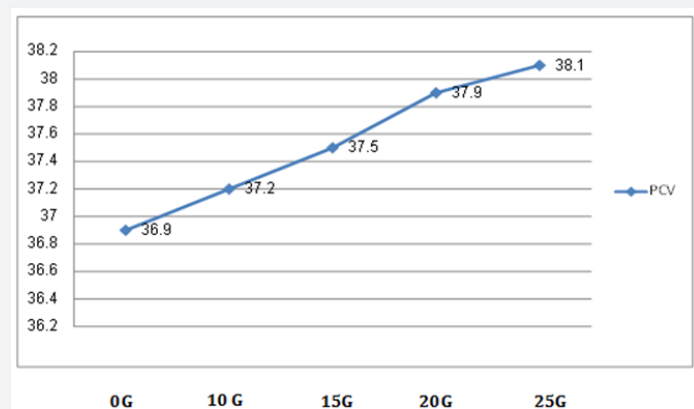

Figure 2: Elevated PCV values after increasing gum acacia dose from 10 grams to 25 grams.

Table 4: $\mathrm{Hb}$ readings (iron contents).

\begin{tabular}{|c|c|c|c|}
\hline Dose & $\begin{array}{c}\text { Readings } \\
\text { before }\end{array}$ & Readings after & p-value \\
\hline 10 grams & 11.821 & $11.78+/-0.893$ & 0.9 \\
\hline 15 grams & 11.821 & $11.99+/-1.075$ & 0.7 \\
\hline 20 grams & 11.821 & $12.0+/-0.95$ & 0.5 \\
\hline 25 grams & 11.821 & $12.1+/-1.149$ & 0.5 \\
\hline
\end{tabular}

Standard reference range values (12.5-15.3 g/dl-female and 14.5$17.5 \mathrm{~g} / \mathrm{dl}$ ) (Figures $3 \& 4$ ).

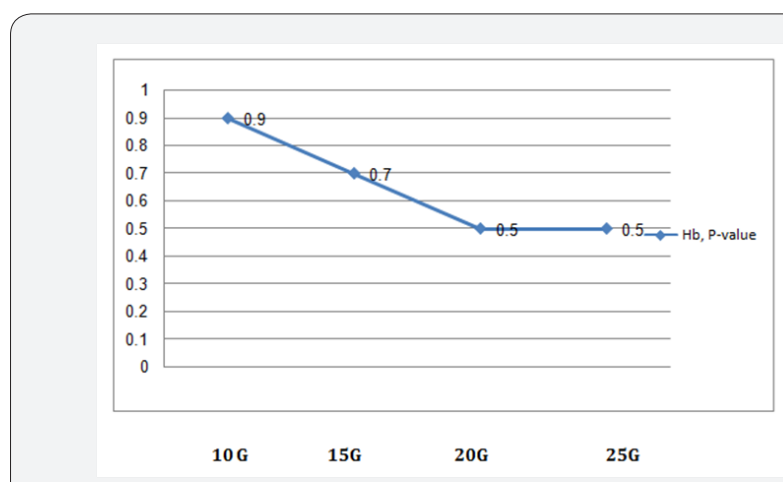

Figure 3: Declined $\mathrm{P}$-values of $\mathrm{Hb}$ readings after increased gum acacia doses administration.

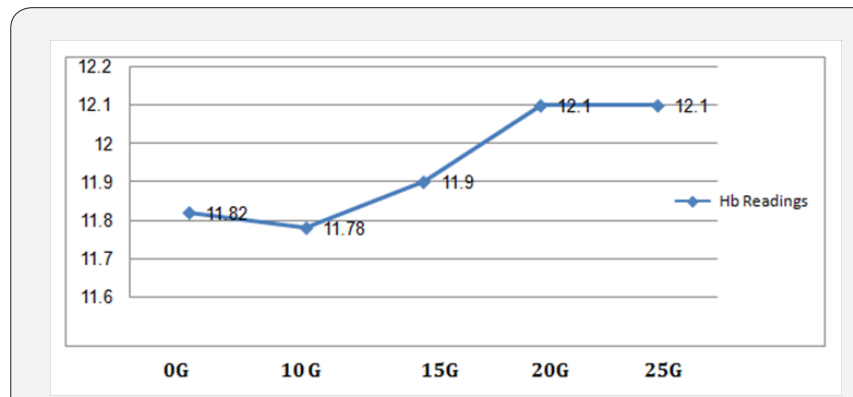

Figure 4: Increased readings of blood iron contents after gum acacia increased dose administration.

\section{Discussion}

Alteration of serum packed cell volume which directly related to iron contents in the blood in patients with renal diseases is well documented in the literature. Gum arabic is frequently used in kidney disease and it showed positive effects in restoring the normal level of PCV in these types of patients. The current study focused on the commonly observed disturbance of PCV in patients with kidney disease. Low hematocrit may indicate a low number of red blood cells, a large number of white blood cells, mineral or vitamin deficiencies, or blood loss, according to Mayo Clinic. This test measures the amount of red blood cells in comparison to other blood cells. First off, we'll look at the low hematocrit level, and what is hematocrit? Simply put, it's the volume of red blood cells within the blood. The total volume of the hematocrit will depend on the number of red blood cells and the size of those red blood cells.

A low hematocrit count in the body is indicative of anemia or hemorrhage. There are many reasons behind anemia; the most common type is iron-deficiency anemia. There are many natural ways to elevate hematocrit levels in the body. Severe forms of anemia, however, need medical intervention together with conservative home remedies. More physiologic markers for the evaluation of iron-restricted erythropoiesis are now available from the hematology laboratory, which can avoid the ambiguity of the traditional biochemical assays in the setting of inflammation. Newer assays for markers of inflammation may allow more targeted management of the anemia in these conditions [14]. The study showed significant association with Gum arabic administration and adjusting the level of serum PCV to normal values (started p-value 0.768 with 10 grams, declined to $\mathrm{p}$-value 0.115 with 25 grams gum acacia), and (the decline $\mathrm{Hb}$ P-value from 0.9 with10 grams to 0.5 with 25 grams).

\section{Conclusion}

There is a significant correlation between Gum acacia and serum Packed Cell Volume depending on the Gum components ratios. These findings reveal a novel effect of GA, which may be used to foster hemoglobin production. This data sheds light on a new era of blood component management that worth further studies. Hence long duration clinical trial (more than 4 months) 
will be beneficial depending on that positive decline in P-value significance and to assess the sustainability of the optimum values and its advantages on clinical events.

\section{References}

1. Miyazaki T, Ise M, Seo H, Niwa T (1997) Indoxyl sulfate increases the gene expressions of TGF-beta 1, TIMP-1 and pro-alpha 1(I) collagen in uremic rat kidneys. Kidney Int Suppl 62: S15-S22.

2. Iida S, Kohno K, Yoshimura J, Ueda S, Usui M, et al. (2006) Carbonicadsorbent AST-120 reduces overload of indoxyl sulfate and the plasma level of TGF-beta1 in patients with chronic renal disease. Clin Exp Nephrol 10(4): 262-267.

3. Powars DR, Elliott-Mills DD, Chan L, Niland J, Hiti AL, et al. (1991) Chronic renal failure in sickle cell disease: risk factors, clinical course, and mortality. Ann Intern Med 115(8): 614-620.

4. Sami A Khalida, Abdelrahman M Musa, Amal M Saeed, Elsir A Abugroun, Elamin 0 Sid Ahmed, et al. (2014) Manipulating dietary fibre: Gum Arabic making friends of the colon and the kidney. Bioactive Carbohydrates and Dietary Fibre 3(2): 71-76.

5. Pearson TC (2001) Evaluation of diagnostic criteria in polycythemia vera. SeminHematol 38(1 Suppl 2): 21-24.

6. Houtmeyers A, Duchateau L, Grünewald B, Hermans K (2016) Reference intervals for biochemical blood variables, packed cell volume, and body temperature in pet rats (Rattus norvegicus) using point-of-care testing. Vet Clin Pathol 45(4): 669-679.

7. Blix M, Hedin SG (1891) "Der Haematokrit" [The Haematokrit]. ZeitschriftfürAnalytischeChemie (in German) 30(1): 652-654.

8. Hedin SG (1891) “Der Hämatokrit, einneuer Apparat zurUntersuchung des Blutes" [The Haematokrit: a New Apparatus for the Investigation of Blood]. Skandinavisches Archiv für Physiologie (in German) 2(1): 13440.

9. WHO (2006) Sickle-cell anaemia-Report by the Secretariat.

10. Aidoo M, Terlouw DJ, Kolczak MS, McElroy PD, ter Kuile FO, et al. (2002) Protective effects of the sickle cell gene against malaria morbidity and mortality. Lancet 359(9314): 1311-1312.

11. Lamis Kaddam, Imad FdleAlmula, Omer Ali Eisawi, Haydar Awad Abdelrazig, Mustafa Elnimeiri, et al. (2015) Gum Arabic as fetal hemoglobin inducing agent in sickle cell anemia; in vivo study. National Heart, Lung, and Blood Institute.

12. Adamson JW, Fialkow PJ, Murphy S, Prchal JF, Steinmann L (1976) Polycythemia vera: stem-cell and probable clonal origin of the disease. N Engl J Med 295(17): 913-916.

13. Wyasu G, Okereke NZ-J (2012) Improving the film forming ability of gum arabic. J Nat Prod Plant Resour 2(2): 314-317.

14. E Rohde (2011) Obituary-Cremation Association of Arkansas, USA.

\section{Your next submission with Juniper Publishers} will reach you the below assets

- Quality Editorial service

- Swift Peer Review

- Reprints availability

- E-prints Service

- Manuscript Podcast for convenient understanding

- Global attainment for your research

- Manuscript accessibility in different formats ( Pdf, E-pub, Full Text, Audio)

- Unceasing customer service

Track the below URL for one-step submission https://juniperpublishers.com/online-submission.php 